\title{
A terra dos Brasis: Um tapete de Flandres jamais visto
}

\author{
Paulo de Assunção \\ Universidade São Judas Tadeu \\ Unicapital \\ Centro Universitário Assunção \\ Doutorando da USP
}

\begin{abstract}
RESUMO
Este artigo discute a descoberta do Brasil a partir dos registros sobre a natureza e do seu significado para a mentalidade do século XVI. Procura-se entender como os primeiros jesuítas descreveram as terras brasileiras, enfatizando as qualidades da natureza tropical.

Palavras-chave: Descoberta do Brasil; jesuítas; natureza.
\end{abstract}

\begin{abstract}
This article analyzes the discovery of Brazil land considering the registers concerning the nature and its meaning for the mentality of XVIth Century. It also intends to understand how the first jesuits described the Brazilian land, emphasizing the qualities of the tropical nature.
\end{abstract}

Keywords: Brazil Discovery; jesuits; nature. 
A sobrevivência no hemisfério sul, desde o período medieval, apresentouse como uma das principais indagações do homem europeu. A falta de informações precisas sobre as regiões abaixo do Equador deu ensejo a conjecturas sobre a vida naquela região, seus habitantes, sua fauna e sua flora. Gomes Eanes de $\mathrm{Zu}$ rara, em Crônica dos feitos da Guiné sobre as terras além do Bojador diz:

não há aí gente nem povoação alguma; a terra não é menos aerosa que os desertos da Líbia, onde não há água, nem árvore, nem erva verde; e o mar é tão baixo que a uma légua de terra não há de fundo mais de uma braça. As correntes são tamanhas, que o navio que lá passe nunca poder tornar. ${ }^{1}$

Seria possível a ampliação das áreas cultivadas na antípoda? Como seria a natureza e os homens nas regiões do Equador? Estas eram as indagações que alimentavam as visões do mito do Paraíso tão desejado, cujos detalhes enriqueciam os relatos de viagem.

As representações das regiões ao sul do Equador, até então, oscilavam entre uma imagem tórrida e uma região aquosa, ambas inabitáveis por se localizarem nos extremos de uma escala que inviabilizava a sobrevivência humana. Desta forma, como destaca Kappler, o alter orbis era um "lugar inacessível onde tudo ocorria ao contrário, já que era a parte de baixo da terra."

218 Esta concepção perdura mesmo após os primeiros reconhecimentos, pois só um número reduzido ou privilegiado de pessoas teve acesso ao alter orbis. As descobertas responderam parcialmente aos questionamentos e mostraram aos olhos do Velho Mundo, ainda incrédulo, a acessibilidade ao alter orbis. A existência de seres biologicamente iguais aos europeus e um mundo natural distinto era possível, mas inferior, pois o referencial eurocêntrico servia de medida para todas as coisas. Américo Vespúcio, em carta a Lorenzo de Medici, em 1503, alude aos novos povos caracterizando-os pelas diferenças: "naqueles países tal multidão de gente encontramos que ninguém enumerar poderia, como se lê no Apocalipse; gente, digo, mansa e tratável." ${ }^{3}$

Thomas More (1478-1535), contemporâneo das grandes descobertas, sintetiza na sua obra A Utopia o deslumbramento da mentalidade do europeu diante do reconhecimento das diferenças dos povos encontrados. Na figura do navegante Rafael Hitlodeu, More destaca como este navegante era o ser vivo que poderia fornecer "os detalhes tão completos e tão interessantes sobre os homens e os países desconhecidos." A comunicação de Hitlodeu ressalta o novo pelo contraste e pelas mutações e diferenças percebidas:

No equador -(...)- de uma parte e de outra, no espaço compreendido pela órbita do sol, não viram senão vastas solidões eternamente devoradas por um céu de fogo. Aí, tudo os aturdia de horror e espanto. A terra inculta tinha apenas como habitan- 
tes os animais mais ferozes, os répteis mais terríveis, ou homens mais selvagens que os animais. Afastando-se do equador, a natureza se abrandava pouco a pouco; o calor é menos abrasador, a terra se cobre de uma ridente verdura e os animais são menos selvagens. Mais longe ainda, aparecem povos, cidades, povoações, em que se faz um comércio ativo por terra e por mar, não somente no interior e com as fronteiras, mas entre nações muito distantes. ${ }^{4}$

Os descobrimentos e a colonização, se por um lado vêm confirmar a idéia de ampliação de um jardim agricultável, percebida através de "uma ridente verdura", por outro revelam ao mundo a diversidade de habitantes, bem como de flora e fauna, não contidas na Bíblia. A realidade recém-encontrada não é afinal tão distante daquela já conhecida. Os habitantes das terras descobertas não se distinguiam daqueles das terras já conhecidas, uma vez que a noção de antípodas e da zona tórrida incluía a existência de uma região com vida, vegetal e humana, ou seja, um outro mundo tão real e humano quanto maravilhoso.

Destarte, a ampliação do jardim cultivado do Éden pode ser compreendida em dois sentidos: o primeiro, da extensão territorial agricultável que aumenta a partir da Europa para o Novo Mundo; e o segundo, da diversidade da dieta do Novo Mundo para a Europa, que o comércio ou trocas poderiam proporcionar. Luis Felipe Barreto, ao considerar as decorrências do processo de descobrimento no campo da cultura, afirma que "os descobrimentos promovem uma contaminação de produtos e técnicas com interesse alimentar que até aí era propriedade exclusiva de determinados espaços isolados". A descoberta de novas terras levava a inferir sobre diferentes culturas, novas espécies de animais e plantas e novas técnicas de cultivo e caça. A circulação cultural pressupunha também uma circulação dos produtos do mundo natural. A flora e a fauna universalizavam-se pelo mercantilismo vigente, e a viabilidade de uma dieta mais farta e variada despontava num "sistema de trocas ao nível das frutas com a deslocação da melancia, da abóbora, da banana, de África para o Brasil e do caju, do maracujá, etc., do Brasil para África". ${ }^{5}$ Silva Dias, ao analisar este momento, ainda classifica os descobrimentos como um "agente de cultura entre camadas extensas da população no sentido da natureza e da sua observação." " A dieta alimentar vai-se ampliando e a natureza torna-se objeto de um olhar mais cuidadoso.

A grande extensão da costa brasileira, já destacada por Pero Vaz de Caminha e pelos primeiros exploradores, a exuberância das paisagens e dos produtos naturais e o encontro de uma cultura desconhecida permeiam os primeiros escritos sobre a Terra de Santa Cruz, revelando o êxtase do europeu perante uma nova diversidade natural.

O Brasil, parte integrante desta nova parcela natural incorporada ao Velho Mundo, surge tal como a América, no seu conjunto, como fonte primária de re- 
cursos que estimula e desenvolve a circulação dos produtos naturais. A natureza universaliza-se com o contato cultural, refletido nos primeiros documentos em cujas narrativas se percebe o deslumbramento à vista das fontes alimentares.

O primeiro relato sobre as Terras de Santa Cruz, a Carta de Achamento de Pero Vaz de Caminha, permite-nos vislumbrar a cosmovisão dos portugueses navegantes sobre o achado, na qual perpassa uma idealização da natureza que se aproxima da imagem idílica, sem contudo evocar um paraíso terral ou o mito da Idade do Ouro.

Pero Vaz de Caminha, após relatar o descobrimento em si e os contatos com os nativos, descreve os elementos naturais da terra, ressaltando a sua grandiosidade e as suas qualidades, onde o mundo natural é percebido na sua diversidade:

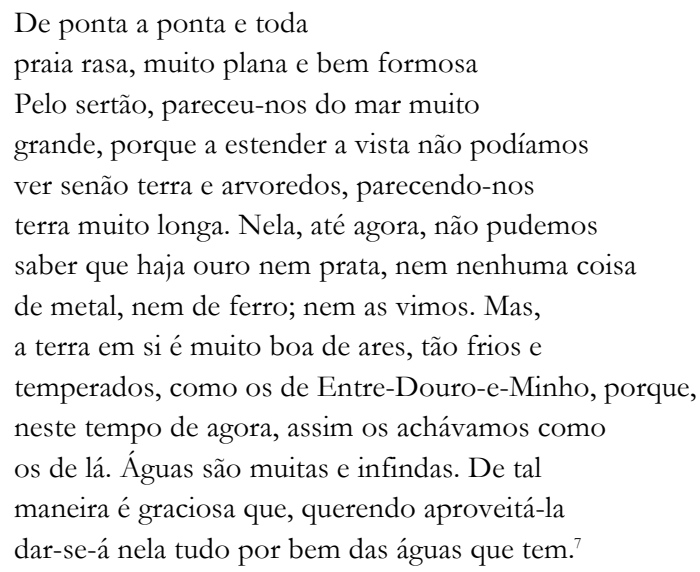

Antonio Pigafetta, ao mencionar a sua passagem pela Terra do Verzino no final de 1519 ressalta, após ter concluído os primeiros contatos de aprovisionamento e troca com o gentio, que a terra é "abundante em toda classe de produtos, sendo que a mesma é tão extensa como França, Espanha e Itália juntas."

Em ambos os relatos, a priori, a natureza é descrita como um conjunto homogêneo, com qualidades positivas e negativas, mas sem diferenças significativas quanto à fauna e à flora. Não se apontam diferenças profundas no contorno delineado das novas terras, mas a exuberância e a diversidade do novo que pode ser povoado e cultivado. O Novo Mundo poderia ser útil, pela sua natureza, ao continente europeu. Os autores quinhentistas impregnaram suas obras de sentido utilitário, em decorrência das necessidades impostas pelos descobrimentos e pela colonização.

No caso brasileiro, esta incorporação do mundo natural ao universo econômico europeu processou-se lentamente, de acordo com as vicissitudes da coroa 
portuguesa e de uma burguesia mercantil que ainda estava voltada para as riquezas do Oriente.

O único recurso economicamente viável da flora brasílica era o pau-brasil, que recebeu regulamentação específica para sua conservação, tendo em vista as desordens advindas de um comércio desregrado nos primeiros anos após o achamento. Desta forma, o rei D. Manuel I emitiu um regimento composto de onze artigos com o intuito de controlar a exploração do pau-brasil, não como forma de preservação do meio natural, mas principalmente como manutenção do poder econômico da coroa e de seus prepostos, abalado por um comércio ilegal da árvore brasílica.

Esta primeira fase do processo exploratório baseava-se no sistema de feitorias, que não permitiu a ocupação do solo. Não havia relatos regulares sobre as terras da América Portuguesa.

Os primeiros jesuítas direta ou indiretamente fizeram uma leitura mais demorada sobre a natureza das novas terras. Os escritos mais fidedignos e mais próximos de uma experiência concreta viriam com a nova política de povoamento da terra. Pelos registros, alguns religiosos, ao descreverem o mundo natural, utilizaram como seqüência o modelo apresentado por Gaio Plínio Segundo (Plínio, o Velho) em sua obra Naturalis historia, que dentre outros assuntos descrevia de forma empírica o céu, as plantas, os animais e as pedras baseado em um conhecimento prático, em que prevaleciam as descrições das coisas como eram vistas. Influenciado pelo pensamento helênico e helenístico que introduz, por meio do Epicurismo, um sistema simbólico, unindo sensação ao objeto concreto, fruto de convenções sociais, Plínio estruturou sua obra a partir da experiência vivencial e influenciou o pensamento durante a Idade Média e início da Idade Moderna.

Os primeiros registros, com variações sensíveis de um jesuíta para outro, tendem a capturar o mundo natural a partir dos quatro elementos: Terra, Água, Ar, Fogo, seguidos por Plínio. Neles a acumulação informativa européia se entrecruzava com uma experiência vivencial indígena, até então nunca concebida. Enquanto observadores e sujeitos, os jesuítas elaboraram a composição do mundo natural brasileiro, dando a conhecer a cultura alimentar da Terra de Santa Cruz.

Os testemunhos jesuíticos centram sua narrativa na terra, naquilo que era passível de conhecimento, pela percepção empírica concernente à qualidade da fauna e da flora. Suas descrições constituíam parte de depoimentos vivenciais. Os religiosos relatavam os animais e as plantas com os quais interagiam, analisando-os e avaliando-os na sua concretitude em relação à existência biológica, sem qualquer viés científico. Conforme frisou Silva Dias, "os jesuítas não prati- 
caram e nem sequer teorizaram ou ao menos reivindicaram significativamente a importância ou o papel da experiência no estudo da natureza."

Destarte, as valorações de cunho genérico ocupam boa parte dos primeiros comentários sobre a terra e dão uma impressão de conjunto da natureza, respondendo às perguntas formuladas acerca do que existiria além do cabo do Bojador.

Estas generalizações decorrem de um conhecimento parcial da terra, típicas dos primeiros registros, por ocasião da chegada dos jesuítas à Bahia ou pela ocupação de novos espaços. Havia a orientação para que as observações fossem muito bem ponderadas, nada deveria ser fornecido em excesso. Logo, as primeiras imagens invariavelmente remetiam ao preâmbulo de cada exercício espiritual proposto por Loyola, em que a composição do lugar material era feita com o auxílio da imaginação, por meio da contemplação.

A primeira descrição da terra feita por Manuel da Nóbrega em abril de 1549, logo após sua chegada à Bahia, revela este tipo de registro. Afirmava o missionário: "A terra cá achamo-la boa e sã", deixando as "mais novas da terra" para um segundo momento, sabendo que "muito há que dizer desta terra." 10

O fator principal ressaltado aqui, no que concerne à terra, é a sua qualificação com adjetivos que apontam para a possibilidade de sobrevivência "boa e sã". Boa para o cultivo e sã para a saúde, fatores fundamentais para o povoamento. Em carta de agosto do mesmo ano, Nóbrega relata ao pe. Simão Rodrigues que a fertilidade e a amplitude da terra permitem o povoamento que pode ser feito com algumas mulheres de vida errada, desde que "não sejam tais que de todo tenhão perdido a vergonha a Deus e ao mundo", justificando que:

todas casariam muito bem, porque é terra muito grossa e larga, e uma planta que se faz uma vez dura $X$ anos aquela novidade, porque, assim como vão apanhando as raízes, plantam logo os ramos logo arrebentam. De maneira que logo as mulheres teriam remédio de vida, e estes homens remediariam suas almas, e facilmente se povoaria a terra. ${ }^{11}$

A fertilidade da terra servia como ingrediente básico na recuperação dos comportamentos desregrados de homens e mulheres. A fertilidade natural impulsionava e permitia a fertilidade humana. Era remédio para o povoamento.

Em carta ao dr. Martin de Azpilcueta Navarro, escrita no mesmo mês, Nóbrega persiste na categoria do genérico aliado ao discurso do povoamento. Nota-se, porém, um pequeno avanço no conhecimento da diversidade do mundo natural, pintado de forma contida, com nuances do maravilhoso e do paradisíaco. Muito mais do que uma pura descrição, as observações que Nóbrega delineia são os esboços de uma representação pictórica da terra dos brasis, que celebra o mundo natural na sua grandiosidade e beleza estética, fruto do ato de criação di- 
vina. Assim se refere Nóbrega à terra brasílica, numa narrativa incomum entre os textos produzidos naquele momento inicial:

E muito sã e de bons ares, de tal maneira que sendo a gente muita e ter muito trabalho, e haver mudados os mantimentos com que se criaram, adoecem muito poucos e esses que adoecem logo saram. É terra muito fresca, de inverno temperada, e o calor do verão não se sente muito. Tem muitas frutas e de diversas maneiras, e muito boas e tem pouca inveja as de Portugal. Mora no mar muito pescado e bom. Os montes parecem formosos jardins e hortas, e certamente nunca eu vi tapete de Flandres tão formoso, nos quais andam animais de muitas diversas maneiras, do quais Plínio nem escreveu nem supôs. Tem muitas ervas de diversos odores e muito diferentes das d'Espanha, e certamente bem resplandece a grandeza, formosura e saber do Criador em tantas, tão diversas e formosas criaturas.

A despeito do tom celebrativo na descrição de um mundo natural brasileiro mais formoso que um "tapete de Flandres", os relatos seguintes, ainda do ano de 1549, enfatizam num primeiro plano a possibilidade de sobrevivência nas novas regiões, pelas qualidades apresentadas. Tal repetitividade leva a crer que, ainda para a mentalidade da época, persiste a idéia de que era inacreditável a sobrevivência fora da Europa. Os relatos inaugurais são um rompimento com a ordem do saber de então. O elemento religioso confirmava que, abaixo do Equador, era possível a existência humana, pois "tem muitas ervas de diversos odores e muito diferente das d'Espanha”. A natureza e os povos da América eram diferentes, com particularidades que o homem europeu deveria reconhecer e se necessário dominar. Qualidades positivas nas terras não faltavam, sendo úteis para o ideal expancionista da fé, uma vez que, segundo Nóbrega, "certamente bem resplandece a grandeza formosura e saber do Criador em tantas, tão diversas e formosas criaturas." "12 A natureza confirma assim o poder do Deus sábio e magnânimo que não poupou esforços para consolidar um natural diverso e formoso.

Nas Informações das Terras do Brasil de 1549, Nóbrega relata aos padres e irmãos da Companhia as informações sobre a terra. Há nestas informações um desejo claro de convencer seus pares a se deslocarem para as terras longínquas, pois, segundo o seu testemunho, eram habitáveis. O homem poderia guardá-las e cultivá-las.

A informação que destas partes do Brasil os posso dar, Padres e Irmãos caríssimos, é que tem esta terra mil léguas de costa toda povoada de gente, que anda nua assim mulheres, como homens, tirando algumas partes muy lexos onde estou onde as mulheres andam vestidas ao traje das ciganas con panos de algodão, pela terra ser mais fria que esta, la qual aqui é muito temperada. De tal maneira que o inverno não é frio, nem quente, e o verão ainda seja mais quente, bem se pode sofrer; porém é 
terra muito úmida, pelas muitas águas, que chove em todo tempo muito a miúdo. Pelo qual os arvoredos e as ervas estão sempre verdes. Há nela diversas frutas, que comem os da terra, ainda que não sejam tão boas como as de lá, as quais também creio que se darian cá, si se plantassem, Porque veio dar-se parras, uvas, e ainda duas vezes no ano; porém são poucas por causa das formigas, que fazem muito dano assim em isto, com em outras coisas. Cidras, laranjas, limões dão-se em muita abundância; e figos tão bons como os de lá. O mantimento comum da terra é um raiz de pau, que chamam mandioca, da qual fazem uma farinha, de que comemos todos. E da também milho, o qual misturado com a farinha faz-se um pão, que escusa o de trigo. Há muito pescado; e também muito marisco, de que se mantêm os da terra, e muita caça de matos, e gansos que criam os Índios. Bois, vacas, ovelhas, cabras e galinhas se tão também na terra, e ai deles muita cópia. ${ }^{13}$

Neste quadro contrastante, pautado pela tônica da abundância, Nóbrega esclarece que, apesar de um meio natural totalmente distinto daquele conhecido em Portugal, a fauna e a flora brasílica eram quase tão boas quanto as da metrópole. As plantas e os animais europeus poderiam adaptar-se a um novo habitat, e com isto era viável a vinda de lavradores e pastores.

A mudança do discurso de uma forma panorâmica para outra pormenorizada permite detectar que a ênfase argumentativa, no que se refere à natureza, vai fixar-se definitivamente na visão utilitária. Isto se percebe nos relatos que explicitam as variedades mais importantes para a dieta alimentar, que antes eram apresentadas genericamente. Acrescida à nomeação dos espaços, encontra-se, já nas primeiras descrições do cultivo, a preocupação com o preparo e o consumo dos gêneros alimentícios fundamentais para a sobrevivência.

A natureza por si só nada era. Dependia do engenho humano para conferir-lhe significado, beneficiá-la para o consumo, torná-la um produto cultural diferente do seu estado in natura.

A observação do mundo natural permite entrever que o olhar jesuítico não se ateve aos limites do espaço convertido. Seu olhar e paladar romperam os limites do espaço cultivado e cristão, para incorporar um reino vegetal e animal exótico e saboroso.

Estas informações, ainda que de cunho pouco abrangente, foram ampliadas pelas cartas seguintes, denunciando que pouco a pouco os inacianos iam-se habituando à natureza, o olho "va haciendo más familiar y al primer efecto de violento contraste con los animales y las plantas de Europa sucede una percepción, imperfecta pero significativa, de las afinidades y semejanzas." ${ }^{14}$ Todavia, poucas cartas se detêm de forma prolongada na descrição minuciosa do mundo natural, revelando que o tema, salvo algumas exceções, assumiu um plano secundário dentro das narrativas.

Somente Anchieta, talvez pelo aspecto místico que lhe atribuem, em alguns 
dos seus escritos apresentou a natureza da América Portuguesa como tema central. Revelando um gênio pragmático, o missionário ultrapassou os estreitos limites da reflexão espiritual com imagens interiores propostas por Loyola, realizando uma leitura cuidadosa da evangelização na sua plenitude. Imbuído de uma visão mística, as considerações da natureza justificavam-se devido ao fim último, desejado por Anchieta, que era a união íntima com Deus.

Ao narrar a fixação no território, o clima desponta nas descrições com relativa constância. Os elementos climáticos, principalmente a temperatura, chamam a atenção dos primeiros missionários recém-chegados, pela sua diferença extremada em relação ao clima da região de origem. Um tempo ameno marca o limite entre o nem frio nem calor da terra dos brasis.

Conforme observou Hitlodeu, o calor tórrido do Equador vai diminuindo com a latitude em direção do pólo Antártico. Por conseguinte, o clima nas regiões descobertas é mais ameno do que aquele na região do Equador e mais agradável do que o do continente europeu. Os jesuítas desejavam, de maneira tímida, confirmar com sua experiência que, após a linha equinocial, a vida era possível.

Até mesmo a astronomia utilizada pelos navegadores eles ignoravam. Quase não se referem a ela durante as suas viagens, seja no percurso de Portugal à Bahia, seja nos trajetos internos.

Ciente da sua incapacidade no que tangia à localização das terras, segundo o conhecimento da época, Anchieta declarou ao tentar localizar a província de São Vicente em 1560, que não era fácil de se detalhar e explicar a aproximação e o afastamento, bem como o curso dos astros, ou as fases da lua, uma vez que nunca tinha estudado, mas que acreditava que estas não poderiam ser diferentes daquelas que se observavam na Europa. Este esclarecimento aponta complexidade e desconhecimento das técnicas de localização, assim como o relativo conhecimento astronômico iniciado pelos humanistas e incorporado à prática dos navegantes, na época.

A ponderação de Anchieta explicita que as técnicas existentes para localização poderiam ser utilizadas também nas novas terras. Não havendo nenhuma censura ou juízo de valor condenatório em tal prática, o mundo era um só e estava sujeito às mesmas leis de verificação. Anchieta, com um olhar mais observador, aproximava-se de um conhecimento científico sem sabê-lo.

Os ventos, as chuvas, os ares foram elementos constantemente observados pelos inacianos. O movimento de ar nas regiões litorâneas, que soprava no final da tarde sobre a terra, acompanhado algumas vezes de precipitações atmosféricas abundantes, contrapunha-se àqueles encontrados na Europa. A oposição pautava a experiência sensorial. Segundo Anchieta,

As estações do ano (olhando de perto) são aqui inteiramente às avessas de lá; no 
tempo em que lá é primavera cá é inverno e vice-versa; mas são tão temperadas que não faltam no inverno os calores do sol para suavizar o rigor do frio, nem no verão as brandas brisas e as húmidas chuvas para regalo dos sentidos; ainda que como já disse esta terra, da beira-mar, é quase todo o ano regada por águas da chuva.

O clima oposto ao da Europa é percebido também pelo calendário das comemorações litúrgicas, quando menciona que o inverno nas terras da América Portuguesa começava em março e acabava em agosto, e o verão começava em setembro e acabava em fevereiro; por conseguinte, as festas do Advento e do Natal ocorriam durante o estio. Nem sempre a definição por oposição ao clima europeu foi possível. Anchieta observava a irregularidade do clima na Capitania de São Vicente, marcando que as estações do ano eram muito diferentes, nem sempre sendo possível distinguir com facilidade o período de primavera e de inverno.

Esta oposição tão marcante do clima brasileiro com características peculiares causou estranheza, mas sossegou a curiosidade dos primeiros loiolanos, pois sabiam que em sua sapiência Deus providenciara o equilíbrio do Cosmos. Anchieta explica tal ocorrência da seguinte forma:

O sol nos seus giros produz uma acerta temperatura constante, de maneira que nem o inverno regela com o frio, nem o verão é demasiado quente, em nenhum tempo do ano param as chuvas, e, de quatro em quatro, de três em três ou até de dois em dois anos, se alterna a chuva com o sol. ${ }^{15}$

Claramente imbuído da teoria geocêntrica ptolomaica, que concebia a Terra como centro do Universo, Anchieta nota, embasado nas constatações concretas, que o giro do Sol ao redor da Terra produzia nas terras dos brasis efeitos diferentes daqueles das terras européias. Comprovava isto pelo clima ameno e regular, sem as durações definidas observadas na Europa.

Esta diferença do giro do Sol produzia também anomalias, mais difíceis de serem explicadas do que as regularidades, e Anchieta, preocupado com a sobrevivência, refere-se a este caso específico, notando que em determinados anos o céu ficava nublado, mas não chovia. $\mathrm{O}$ excessivo calor e a falta de água não permitiam o crescimento de bons frutos. Em outros anos, marcados por chuvas excessivas, as raízes plantadas acabavam apodrecendo.

As impressões sobre o clima confirmavam, apesar das irregularidades, a possibilidade da existência humana abaixo da linha do Equador. O clima suscitava ainda indagações sobre o caráter dos seres que habitavam as terras abaixo da linha equatorial.

No século XVI, vigorava ainda a concepção de Hipócrates quanto a atribuir ao ar uma influência importante na formação dos indivíduos. A escola hi- 
pocrática defendia "a influência dos ares e dos lugares no desenvolvimento do feto, na elaboração dos temperamentos, na gênese das paixões, nas formas de linguagem e no gênio das nações." ${ }^{16}$

Anchieta, em Informação da Província do Brasil de 1585, registra a permanência desta concepção que sobreviveu ao período medieval, quando descreve a benignidade do clima, no que diz respeito à longevidade dos seus habitantes:

O clima desta província do Brasil é geralmente muito temperado, de bons e delicados ares e muito sadios, aonde os homens vivem muito, até oitenta, noventa e mais anos, e a terra está cheia de velhos. Não tem frios nem calores grandes, os céus são mui puros, máxime à noite; a lua é mui prejudicial à saúde e corrompe muito as cousas, as manhãs são salutíferas, tem pouco de crepúsculo porque em amanhecendo logo sai o sol e em pondo-se anoitece. ${ }^{17}$

Por esta boa fama dos ares tropicais é que o pe. Miguel Torres informa ao pe. Diego Laynez a ida do jesuíta Dictio, "que tem a enfermidade de gota", para o Brasil, justificando a decisão não só pela utilidade que este teria para a conversão, mas "especialmente se enviou porque aqui [Portugal] não havia esperança ordinariamente de saúde, e lá segundo dizem os médicos, a cobrará com os ares e exercícios da terra se em alguma parte a pode cobrar." ${ }^{18}$

Contudo, os ares e o clima não eram vistos só pela sua benignidade. Quando considerado em função de uma moralidade cristã, o clima era visto pela sua influência maligna no comportamento dos habitantes.

Os ares das terras equatoriais e subtropicais permitiam a nudez indígena. A exposição do corpo e principalmente da genitália, rompendo com os preceitos cristãos de moralidade, significava a negação da moral cristã. O clima contribuía para a perpetuação dos costumes da terra e era uma barreira natural à conversão.

A influência do clima de forma negativa também era passível de ser constatada na fauna pela procriação de determinadas espécies que comprometiam a própria existência dos jesuítas. Anchieta entendia que a abundância de animais imundos era decorrente desta negatividade do clima que influía peçonha nos animais e serpentes, que nesta terra se criavam muitos e de diversos tipos como ratos, morcegos e aranhas. ${ }^{19}$

A despeito dos aspectos pouco favoráveis normalmente apontados pelos primeiros missionários, o clima da terra dos brasis foi considerado benigno e agradável pela preponderância de temperaturas moderadas que favoreciam a saúde e facilitavam a adaptação do homem, principalmente daqueles que acabavam de chegar.

Se por um lado a terra era considerada boa e sã, por outro ela incomodava 
os jesuítas com as doenças tropicais: "Alguns outros Irmãos são também visitados do Senhor com enfermidades, como febres, prioris (pleurisia) e camaras, mas ele que as dá as cura pela sua misericórdia, que nesta terra poucas medicinas há para ele, bendito seja ele por tudo."

A doença permite delinear um quadro mais intenso e dramático para a atividade missionária. Anchieta, relatando as atividades exercidas pelos jesuítas em 1562, inclui nas considerações que o atendimento das enfermidades era um ato tão comum quanto o de predicar a doutrina:

acodenos a todo gênero de pessoas, portugueses e brasil, servo e libre, assim nas cosas espirituais como nas corporais curando-los e sangrando-los, porque não há outro que o faça, e principalmente las sangrias são aqui muito necessárias, porque es muito sujeita esta terra a prioris, maxime nos naturais dela, quando o sol torna declinar fazia el norte, que é no mes de Dezembro e dali por diante. ${ }^{20}$

Tal como os membros fundadores da Companhia, nos primeiros anos após o voto de Montmarte, os jesuítas tiveram que auxiliar na cura das doenças da terra, enquanto preceito natural da caridade ao próximo.

A prática da medicina tornou-se comum e foi compreendida como atividade associada à ação jesuítica. Contudo, com o crescimento das vilas, esta prática provocou a preocupação dos jesuítas, quando o padre geral interditou qualquer exercício neste sentido. Mas ante as evidências foi solicitado ao padre geral que reconsiderasse a proibição, uma vez que em muitas situações era de extrema necessidade a sangria, pois sem ela muitos ficavam enfermos e morriam, como havia ocorrido em anos passados. A resposta do padre geral foi favorável, entendendo que não havia inconveniente que os irmãos coadjutores temporais, que tivessem o conhecimento da sangria, fizessem tal prática quando fosse necessário, ressalvando ainda que isto era possível tendo em vista que estes não iriam se ordenar.

Esta proximidade da medicina com a prática catequética não era totalmente desprovida de significado. A doença para o jesuíta, como também para a maioria da população européia, era oriunda não de uma debilidade do organismo humano, mas sim de uma debilidade ético-moral.

Dentro desta óptica, na maioria dos casos, as doenças e a mortandade eram consideradas como influência do Diabo e, portanto, deviam ser curadas principalmente no plano espiritual, para depois serem tratadas no plano material - uma decorrência do primeiro. Nesta perspectiva, a doença antes de ser uma debilidade física era a manifestação do mundo de forças malignas que deviam ser expulsas dos pacientes.

Leonardo do Vale, ao descrever a cegueira em que vivia o gentio nos seus 
ritos e venerações, confirma que tais práticas redundam em vícios tidos como diabólicos. O castigo divino era a fome e a mortandade que grassava sobre os índios. Desta forma, as doenças eram vistas como uma punição enviada por Deus. Leonardo do Vale cita um castigo enviado aos índios, afirmando que:

(...) de maneira que seu peccado foi castigado com huma peste tão estranha que por ventura nunqua nestas partes ouve outra semelhante. Alguns querem dizer que se pegou da nao em que veio Pe. Francisco Viegas, porque começou nos Ilheos onde ella foy aportar. Mas parece mais certo ser açoute do Senhor, e começar donde os remeiros primeiro começarão a correr à sanctidade, que andava polo certão adentro. E o mesmo se pode dizer da fome, que casi hé geral antre elles, porque nesta terra nem ha muita agoa nem o muito sol causa fome como em portugal e outras partes, mas en todo ho tempo, que hum quiser trabalhar e pôr ho terço da diligencia que põem hos lavradores da Beira e Alentejo, terá que comer e que dar. ${ }^{21}$

A preocupação com a doença tinha um olhar mais amplo que o estreito limite do organismo biológico humano. O momento de debilidade física era propício para a realização da cura não só do organismo debilitado, mas também do espírito, onde a água, enquanto elemento purificador, marcava a conversão do indivíduo, sendo que a recuperação física nem sempre ocorreu. Anchieta afirma:

Alguns homens tambem assistem, aos Domingos, á celebração da Missa, e nessa ocasião, depois do ofertório, se lhes prèga alguma coisa a respeito da fé, da observancia dos mandamentos e além disso, o que é pouco, atendendo á sua rude natureza, nenhum dia deixamos passar, sem que vamos a sua casa, exortando ora uns, ora outros a aceitar a fé, tomando parte na sua conversação, e tratando com eles na maxima familiaridade; com especialidade aqueles a quem êste encargo é imposto pela obediencia: pois que as conversações particulares os impressionam muito, ao verem o nosso esfôrço e o nosso cuidado, não podem deixar de admirar e reconhecer o nosso amor por eles, principalmente, porque vêm que empregamos toda a diligência no tratamento de suas enfermidade, sem nenhuma esperança de lucro. E fazemos isto, na intenção de preparar para o recebimento do batismo, caso haja necessidade, os seus espíritos, em tais circunstâncias mais redutiveis e mais brandos: por igual motivo é que desejamos assistir ás parturientes, afim de batizar mãe e filho, se o caso exigir. Assim acontece atender-se á salvação do corpo e da alma. ${ }^{22}$

A terra dos brasis, destacada pelos seus bons ares, também era considerada propícia para a cura dos males. A salubridade decantada visava a chamar a atenção para a vinda de novos irmãos para as terras brasileiras, principalmente daqueles que residiam em Coimbra, mal dispostos, porquanto a terra sendo boa e os trabalhos muitos, logo ficariam curados, conforme a experiência tinha mostrado com outros companheiros que haviam chegado a esta terra. 
A benignidade dos ares era um sinal de acolhimento para os filhos doentes de Santo Inácio. Na terra dos brasis, a Companhia poderia ganhar fôlego e crescer.

Luís da Grã, exaltando o caráter terapêutico dos bons ares da terra, relata ao pe. João Gonçalves que as

ocupações eram de ensinar os meninos que a cargo temos e ter cuidado de dar ordem ao que era necessário para sustentação dos meninos, que é farto trabalho para sua disposição: que por graça do Senhor foi sempre em muito notável aumento, vindo do Reino sem remédio humano de saúde, porque não puderam fazer tantos os muitos que o procuraram no Reino, quanto fez a terra com tão bons ares como tem: que sem dúvida os velhos e de fraca complexão a sentem muito a propósito para sua saúde corporal, y de todas as partes do Brasil se diz o mesmo. ${ }^{23}$

Anchieta percebia também a potencialidade da própria terra no tratamento de males, que em Portugal eram difíceis de serem curados. Os ares da terra e um tratamento terapêutico ímpar levaram o missionário a descrever o tratamento do cancro, cuja cura ele comprovara:

O cancro (que lá é tão difícil de curar) cura-se facilmente pelos Índios. Eles à doença, que é a mesma que entre nós, chamam (...); e curam-na assim: do barro, de que fazem vasilhas, aquecem ao fogo um pouco, bem amassado e, tão quente quanto a carne o possa suportar, aplicam-no aos braços em cranco, que pouco a pouco morrem; e repetem isto tantas vezes até que, mortas as pernas e o corpo, o cancro desprende-se e cai por si. Há pouco se provou isto por experiência com uma escrava dos portugueses quando padecia de doença. ${ }^{24}$

A salubridade e a potencialidade da terra dos brasis constituía um dos pontos positivos da terra que, por vezes, apresentava aspectos negativos. Na complexa escala valorativa que o jesuíta elabora para sua análise sobre a terra, notase um antagonismo latente quanto à classificação das terras no seu conjunto. A própria trama argumentativa ora destaca a vitalidade da terra, acenando para as vantagens da vida e da prática missionária, ora tenta enfatizar a penúria, visando a dar destaque ao perfil de sofredor do jesuíta, assinalando um empecilho concreto para a vinda de novos loiolanos.

Destarte, apesar dos bons ares, a terra não dispunha de boa alimentação para a cura dos doentes. Ambrosio Pires relatou esta constatação ao pe. Diego Mirón, para corrigir a possível incompreensão da realidade que envolvia a atividade catequética. Referindo-se aos meninos órfãos que acabavam de chegar à terra brasílica, o missionário afirmava que estavam preocupados com os poucos agasalhos que possuíam, e apesar de terem boa farinha de pau, a terra era muito ne- 
cessitada de carne e peixe e das coisas necessárias para os enfermos, concluindo: "porque das coisas dos sãos há poucas e das doentes nenhumas."25

Segundo esta observação do pe. Ambrosio, a constância da falta de recursos para a cura dos doentes parece ter sido comum. Nem todos aqueles que para cá se dirigiram tiveram a mesma sorte que o pe. João Gonçalves. Pela falta de medicamentos do reino, o doente ficava sujeito aos medicamentos e mezinhas da terra, forçado a um contato direto com o reino vegetal, na busca de poção que o curasse. A cura das doenças naturais ou dos ferimentos provenientes da guerra só poderia ser feita com a flora local, unindo o saber indígena ao europeu. A doença e sua cura parecem ter sido também uma forma de confirmar a visão utilitária da natureza, em que os saberes de duas culturas distintas interagiram, deixando transparecer as várias propriedades terapêuticas da flora.

No relatório quadrimestral de setembro de 1556 a janeiro de 1557, redigido pelo irmão Antônio Blázquez, há o relato de atividades do pe. João Gonçalves e do irmão José de Anchieta, afirmando:

Entre outras enfermidade[s] que com a ajuda sarou, foi essa uma, que estando uma índia muito ao cabo de camaras, e não tendo remédio os parentes com que as estancar, lhe fez ele uns emplastos com acelga e azeite (porque cá não há outros materiais) e logo a deu sã, ficando por esta cura acerca dos negros em grão reputação. ${ }^{26}$

Azpilcueta Navarro, ao narrar a sua viagem pelo interior do território, menciona que após árduas caminhadas e perigos sempre iminentes, ele e seus companheiros de viagem foram vítimas de índios que atacaram os membros da comitiva, ferindo alguns deles. Para curá-los, segundo o loiolano, existia somente o mel silvestre, que foi usado com bastante eficiência. ${ }^{27}$

A descrição dos males da terra em algumas cartas era acompanhada de referência sobre a flora medicinal que possibilitava a cura. Anchieta, em carta ao padre geral em 1560, narra as "coisas naturais" da Capitania de São Vicente, ressaltando que úteis à medicina havia muitas árvores e raízes de plantas, e dentre elas destacava aquelas proveitosas como purgantes. Preocupado com a purgação dos males do corpo, Anchieta descreve:

Há uma certa árvore, de cuja casca com faca, ou do galho quebrado, corre um líquido branco como leite, porém mais denso, o qual se beber em pequena porção, relaxa o ventre e limpa o estômago por violentos vômitos; por pouco, porém, que se exceda na dose, mata. Deve-se, enfim, tomar dele tanto quanto caiba em uma unha e isso mesmo diluído em muita água; se não se fizer assim, incomoda extraordinariamente, queima a garganta e mata.

Tal como a mandioca, o leite da árvore terapêutica poderia restabelecer o 
equilíbrio orgânico ou provocar a morte. O benefício ou malefício dependia do conhecimento humano. Anchieta refere-se também a outras duas raízes menos nocivas que a primeira - mas tão úteis quanto aquela - que eram abundantes nos campos. Sua ingestão era feita após a raspagem e a mistura com água, provocando vômito com violência, sem comprometer a vida do doente. Além desta, outra se destaca com o nome de "marareçô", cujas folhas eram parecidas com as do boldo, "a raiz pequena e redonda, que se come assada ou bebe-se esmoída com água, exposta por uma noite ao sereno". A natureza por si só nada era. Sua função utilitária derivava da sua importância para o homem e do seu preparo. Os males constantes que afligiam os colonos e jesuítas fizeram que novas árvores fossem incorporadas ao rol das plantas medicinais. Temia-se a morte por um excesso de cura ou de um preparo indevido. Na mesma carta, relatava Anchieta que havia descoberto uma outra planta com folha oblonga e delgada que, macerada e deixada de infusão pelo período de uma noite e ingerida pela manhã, não causava náusea nem fastio, ajudando no alívio do ventre com abundante fluxo, que cessava logo que algum alimento fosse ingerido.

Anchieta cita uma outra árvore da qual se extrai uma resina com poder para curar feridas:

Das árvores uma parece digna de notícia, da qual, ainda que outras bajas que distilam um líquido semelhante a resina, útil para remédio, escorre um suco suavíssimo, que pretendem seja o bálsamo, que a princípio corre como óleo por pequenos furos feitos pelo carrancho ou também por talhos de foices ou de machados, coalha depois e parece converter-se em uma espécie de bálsamo exala um cheiro muito forte, porém suavíssimo e é ótimo para curar feridas, de tal maneira que em pouco tempo (como dizem ter-se por experiência provado) nem mesmo sinal fica das cicatrizes. ${ }^{28}$

O discurso segue a mesma forma usada nas passagens anteriores. O objetivo da narração é fornecer dados sobre o processo de obtenção da resina, suas características (cor, forma, odor) associadas a outras espécies da flora conhecidas pelo destinatário, e as propriedades terapêuticas da planta.

Nem só da resina das plantas se obtinham as mezinhas para a cura dos males. Outras variedades de frutas e raízes também tinham o seu uso voltado para a medicina.

Nóbrega, por sua vez, demonstrou as propriedades dos ananases. Ao enviar conservas para pe. Francisco Henrique, disse que os ananases são "para dor de pedra, os quais posto que não tenham tanta virtude como verdes, todavia fazem proveito." ${ }^{29}$ Dentre outros produtos da terra, Anchieta destaca as raízes de um tubérculo com "agradável sabor" as quais compara com o rabão, que é o yeticopê, sendo que estas raízes são "muito apropriadas para acalmar a tosse e mo- 
lificar o peito", ressaltando ainda que a semente, que "se assemelha a favas, é um violentíssimo veneno." ${ }^{30}$

A medicina, sem dúvida, foi uma das maiores beneficiárias dos descobrimentos. As plantas medicinais encontradas na América, principalmente no Brasil, contribuíram para um melhor conhecimento da utilização de algumas espécies e ampliavam os horizontes informativos sobre a botânica. O discurso jesuítico, de maneira indireta, contribuiu para o reconhecimento de novas espécies da flora medicinal e para a ampliação das técnicas de tratamento utilizadas. As vias do saber médico eram norteadas pelo empirismo marcado por uma evidência existencial, em que o mundo natural era conhecido pelas experiências decorrentes da observação e constatação visual das causas e efeitos, complementadas pelo processo comparativo, do qual o modelo-padrão era o europeu. Portanto, as descrições dos jesuítas, enquanto frutos de uma experiência do cotidiano, compartilhavam de uma similitude de procedimento, pois o que funda o acontecimento digno de ser narrado é a conjunção de uma constatação visível, que pode ser reproduzida e comprovada (causa-efeito) e que se faz importante pela sua utilidade. Manter a saúde dos cristãos na terra dos brasis era fundamental.

Embora alguns jesuítas se valessem nos seus registros da separação da natureza em quatro elementos: Terra, Água, Ar e Fogo, sistematização empreendida por Empedócles e utilizada por Plínio no início da Era Cristã, na sua obra Naturalis historia, nota-se que a característica preponderante das referências foi a utilização das analogias que permitiam uma melhor compreensão da riqueza e da diversidade do mundo natural da América Portuguesa. Os primeiros jesuítas captaram a natureza na relação direta da necessidade que a existência terrena exigia, em que afloravam mais as percepções de senso comum. Um mundo natural, onde tudo era útil, onde tudo poderia ser convertido em prol da necessidade humana, sintetizava a concepção de natureza feita por uma cultura influenciada pelo cristianismo.

Marcada pela predominância do pensamento judaico-cristão que se sobrepôs ao pensamento helênico e humanista, a natureza era vista como produto da criação divina, criada para os seres humanos. A natureza por si só nada era; quem lhe conferia significado era o homem, que necessitava dos produtos naturais para a sua sobrevivência.

A natureza era concebida de forma dual: vida e morte se mesclavam no horizonte mental dos loiolanos. Esta elaboração decorrente da existência humana confirmava que o homem precisava satisfazer as suas necessidades biológicas, ao mesmo tempo em que sinalizava para a sua dominação sobre o mundo. A terra dos brasis era reconhecida e conquistada, mostrando sua beleza jamais vista em um tapete de Flandres. 


\section{NOTAS}

${ }^{1}$ Citado por DIAS, J. S. da Silva. Os descobrimentos e a problemática cultural do século. Lisboa: Editorial Presença, 1982, p.56.

${ }^{2}$ KAPPLER, Claude, Monstros, Demônios e Encantamentos no fim da Idade Média. Tradução de Ivone Castilho Benedetti, São Paulo: Martins Fontes, 1994, p. 43.

${ }^{3}$ VESPÚCIO, Américo, Novo Mundo. Tradução de Renato Martins, Porto Alegre: L\&PM, 1987, p. 93.

${ }^{4}$ MORE, Thomas. “A Utopia”. In Os Pensadores. São Paulo: Nova Cultural, 1988, pp. 168-169.

${ }^{5}$ BARRETO, Luiz Felipe. Os Descobrimentos e a Ordem do Saber. Lisboa, Gradiva, 1987, pp. 15-16.

${ }^{6}$ DIAS, J.S. da Silva. Op. cit., p. 64.

${ }^{7}$ VALENTE, José Augusto Vaz. A carta de Pero Vaz de Caminha: estudo crítico, paleográfico, diplomático. São Paulo: Museu Paulista da Universidade de São Paulo, 1975, fl. 13, v-8-21.

${ }^{8}$ Conforme Amoretti: verzino ou pau-brasil é o nome da madeira vermelha que se importava antes da Ásia e África. PIGAFETTA, Antonio. A Primeira Viagem ao Redor do Mundo. Trad. de Jurandir dos Santos, Porto Alegre: L\&PM, 1986, pp. 57 e 75.

${ }^{9}$ DIAS, J. S. da Silva. Op. cit., p. 41.

${ }^{10}$ Carta do pe. Manuel da Nóbrega. In LEITE, Serafim. Cartas dos primeiros jesuítas do Brasil. São Paulo, Comissão do IV Centenário da cidade de São Paulo, 1954, vol. I, p. 115.

$234{ }^{11}$ Carta do pe. Manuel da Nóbrega. In LEITE, Serafim. Op. cit., vol. I, p. 120.

${ }^{12}$ Carta do pe. Manuel da Nóbrega. In LEITE, Serafim. Op. cit., vol. I, pp. 135-136.

${ }^{13}$ Informação das Terras do Brasil. In LEITE, Serafim. Op. cit., vol. I, pp. 147-148.

${ }^{14}$ GERBI, Antonello. La Naturaleza de Las Indias Nuevas. Trad. Antonio Alatorre, México: Fundo de Cultura Economica, 1992, p. 31.

${ }^{15}$ Carta do ir. José de Anchieta. In LEITE, Serafim. Op. cit., vol. III, pp. I-III.

${ }^{16}$ CORBIN, Alain. Sabores e Odores. Trad. de Ligia Watanabe, São Paulo: Cia. das Letras, 1987, p. 22. Ver também KAPPLER, Claude. Op. cit., p. 48.

${ }^{17}$ Informação da Província do Brasil. In Cartas Jesuíticas III - Cartas, Informações, Fragmentos históricos e Sermões do Pe. Joseph de Anchieta, S.J. (1554-1594). Rio de Janeiro: Civilização Brasileira, 1933, p. 424.

${ }^{18}$ Carta do pe. Miguel de Torres. In LEITE, Serafim. Op. cit., vol. III, p. 164.

${ }^{19}$ Informação da Província do Brasil. In Cartas Jesuíticas III, p. 432.

${ }^{20} \mathrm{Carta}$ do ir. José de Anchieta. In LEITE, Serafim. Op. cit., Vol. III, pp. 453-454.

${ }^{21}$ Carta do pe. Leonardo do Vale. In LEITE, Serafim. Op. cit., vol. IV, p. 9.

${ }^{22}$ Trimestral de maio a agosto de 1556, de Piratininga. In Cartas Jesuíticas III, p. 88.

${ }^{23}$ Carta do pe. Luís da Grã. In LEITE, Serafim. Op. cit., vol. II, p. 130.

${ }^{24}$ Carta do ir. José de Anchieta. In LEITE, Serafim. Op. cit., vol. III, p. VII.

${ }^{25}$ Carta do pe. Ambrósio Pires. In LEITE, Serafim. Op. cit., vol. II, p. 232. 
${ }^{26}$ Quadrimestre de setembro de 1556 a janeiro de 1557 pelo ir. António Blazquez [?]. In LEITE, Serafim. Op. cit., vol. II, p. 355.

${ }^{27}$ Carta do pe. Juan de Azpilcueta Navarro. In LEITE, Serafim. Op. cit., vol. II, p. 244.

${ }^{28}$ Carta do pe. José de Anchieta ao pe. geral. In Cartas Jesuíticas III, p. 126.

${ }^{29}$ Carta do pe. Manuel da Nóbrega. In LEITE, Serafim. Op. cit., vol. II, p. 351.

${ }^{30}$ Carta do pe. José de Anchieta. In Cartas Jesuíticas III, p.125.

Artigo recebido em 10/1999. Aprovado em 09/2000. 